\title{
Prevalence and Factors Related to Delayed Disclosure of Child Sexual Abuse in Benha region, Egypt during the Period 2016-2018
}

\author{
Fatma M. Elgazzar ${ }^{1}$, Mohamed S. Abdelaziz ${ }^{2}$ and Heba K. Khalifa ${ }^{1}$ \\ ${ }^{1}$ Forensic Medicine and Clinical Toxicology Department, Faculty of Medicine, Tanta University, Tanta, Egypt \\ ${ }^{2}$ Benha Department, Forensic Institute of Ministry of Justice, Egypt
}

\begin{abstract}
Introduction: Child sexual abuse (CSA) is a serious breach of a child's basic human rights. A variety of distressing short-term and long-term consequences might occur. Lack of reporting by the victims makes determination of actual prevalence rates for CSA difficult. Aim: This study aimed to assess the prevalence of child sexual assault and to identify factors related to its delay reporting by the victims. Methods: This retrospective study was conducted in Benha Medico-legal Department, Ministry of Justice, from the start of 2016 to the end of 2018. Detailed medicolegal report of every case was obtained to fulfill personal data, assault data and data of general and local examination of the victims. Results: The total number of cases in the study was 155. Most of them were females aged between 12-18 years. Anal sex was more frequent among males (91.2\%) while, rape, attempted rape, and mixed assault occurred only in females with statistically significant association between gender of victim and the type of sexual assault. It was found that gender of victim was significantly related to delayed disclosure. Additionally, there was a statistically significant association between both the victim's and the assailant's ages and delayed disclosure $(\mathrm{p}<0.00)$. Conclusion: Sexual child abuse is a problem in our society and its reporting by the victims was often delayed. Recommendations: Female children should be encouraged by their families to report any attempt of sexual abuse early for proper documentation and protection of their rights. Furthermore, consistent methods and checklist for defining and reporting cases of CSA are required both in general hospitals and medicolegal institutions. There by proper preservation and collection of medical evidence could be achieved; to avoid the problem of lost data and the victim's rights.
\end{abstract}

Keywords Child sexual abuse, anal sex, rape, prevalence, delayed disclosure.

\section{Introduction}

7 hild abuse is a serious breach of a child's basic human rights. Actually, it is the consequence of different familial, social, psychological, and economic factors (Featherstone et al., 2017).

Child sexual abuse (CSA) ensue when a developmentally unprepared child is engaged in sexual activity where the child cannot realize or give consent. Sexual abuse includes oral-genital, genital, or anal contact. However, exhibitionism, voyeurism, or using the child in the production of pornography are considered non- contact child abuse (Morris et al., 2019).

Various injuries might result from child sexual abuse. This depends on the age and body built of the child and the degree of force used. In severe cases, CSA may cause damage to internal organs and bleeding that, in some cases, may end by death (IngemannHansen and Charles, 2013)

Child sexual abuse is a great threat to a child's well-being. A variety of distressing short-term and longterm consequences might occur. These include psychological, emotional, physical, mental and social effects (Chen et al., 2014). Moreover, substance abuse, aggressive destructive behavior, future criminality and/or suicide attempts might also follow (Mutavi et al., 2018, Kim et al., 2017).

Lack of reporting makes determination of actual prevalence rates for CSA difficult (Singh et al., 2014). Furthermore, it is necessary for the evidence of child sexual abuse in the reported cases to be of high accuracy to guarantee legal validity. Actually, diagnosis of CSA still depends mainly on the child's allegation. This is because in most sexual assault's examination, children do not have diagnostic physical findings of sexual abuse. Therefore, the child's disclosure of the incident is often the most important clue for determining the probability of abuse (Sakelliadis et al., 2009).

Previous research on gender differences and delay of disclosure of child sexual abuse is inconclusive; some research has found that male victims are more likely to delay disclosure than female victims, while other studies have found no gender difference (Coburn et al., 2019).

Therefore, the aim of this study was to assess the prevalence and profiles of child sexual assault. Furthermore, to identify factors related to delayed reporting by the victims. 


\section{Patients and Methods}

Ethical approval, setting, study design, and duration: This study was conducted in Benha Department, Forensic Institute of Ministry of Justice after an official permission of the Head of the institution. The study was also approved from the research ethics committee, Faculty of Medicine, Tanta University. Confidentiality of data was maintained by keeping the records anonymous. This retrospective study was carried out over a three-years period from the start of 2016 to the end of 2018.

\section{Inclusion criteria:}

The study included all the victims of child sexual assault examined in Benha Department, Forensic Institute of Ministry of Justice during the period of the study.

\section{Data collection:}

Detailed medicolegal report of every case was obtained to fulfill the following information: Personal data including gender, age, residence, and mental status. Assault data including date of incidence, date of examination, delay time (time between the assault and its reporting, assault place, and the type of sexual assault; rape (which means forceful vaginal penetration of a women by man's penis, Russell, 1984), attempted rape, anal sex, and mixed rape and anal sex. The age and the number of the assailants, and whether the assailant was a relative to the victim or strange were also collected. Further, data of medicolegal examination including general examination of the body of the victim for the presence of any injuries and their types were obtained. Additionally, data of local examination of the vulvo-vaginal region including labia majora, labia minora, clitoris, posterior fourchette, hymen (type injury), vaginal wall, and vaginal swab results if it was obtained were recorded. Detailed anal examination for skin corrugations, anus opening, adjacent area, anal reflex, sphincter tone, presence of tear of anal mucosa (recent - old), and anal swab results were also recorded.

\section{Statistics:}

Statistical analysis and presentation of data was conducted using SPSS (Statistical Package for the Social Sciences) version 22 computer program. Categorical data were presented as numbers and percentages. Chi-Square or Fisher's Exact tests as appropriate were applied to investigate the association between different variables. Level of statistical significance was considered at $\mathrm{P}<0.05$.

\section{Results}

The total number of recorded cases of CSA during the period of the study (2016 to 2018) was 155. Table (1) demonstrates that the highest percentage $(43.2 \%)$ of sexual assaults was encountered in 2018. The majority $(65.8 \%)$ of victims were female, while males represented $34.2 \%$. Regarding the age of victims; the youngest reported case was 3 years old and the oldest victim was 18 years. Children aged 12-18 years represented the highest percentage of assault victims (56.8\%). More than two-thirds (67.7\%) were from urban while, $32.3 \%$ were from rural areas. Only one case was died while the remaining 154 victims were alive. Regarding the victim's mental state, only one victim in this study was mongoloid. Table (1) shows also no significant differences in the characters of CSA victims between the studied three years $(\mathrm{p}>0.05)$.

The most frequently reported type of sexual abuse during the duration of this study was anal sex (36.8\%), followed by attempted rape (30.3\%), then 44 cases (28.4\%) were exposed to rape, while the least frequent type was both vaginal and anal assault (4.5\%) as shown in table (2). Additionally, in ninety cases (58.1\%) of this study, the duration between the assault and reporting the incident was more than 3 days, with no significant differences between the three studied years (Table 2).

As regards the age of the assailant, table (3) shows that the highest percentage of assailants aged more than 18 years old (60.0\%). Additionally, single and non- relative assailants were more predominant (87.1\% and $93.5 \%$ respectively).

The majority of child victims (76.1\%) showed no traumatic lesions in their body during general examination, while 37 (23.9\%) cases represented with signs of general injury. Limbs (14.2\%) were the most common site of traumatic lesions, followed by face (3.2\%). The back (1.9\%) of the child cases was the least common site that was affected during the sexual assault. Abrasions (12.9\%) were the most frequent wound in CSA cases, followed by bruises (7.1\%). Five cases (3.2\%) exposed to burn while only one case showed bites as shown in table (4).

Local examination of vulvo-vaginal and perineal regions in the victims exposed to rape, attempted rape and mixed assault (98cases) revealed that hymen tears were detected in $40.8 \%$ of cases. Vaginal swabs were taken from 13 cases, positive swabs for presence of semen were found in $8(8.2 \%)$ of the cases Table (5).

Examination of anal region in cases of anal sex and in mixed rape and anal sex (64 cases) revealed signs of chronic habit of anal sex in 14 (21.9\%). These included weak anal reflex and sphincter tone, flat skin corrugation, in addition to wide anal opening and flat anal canal. Anal swabs were taken from 8 cases, positive swabs for presence of semen were found only in 5 (7.8\%) of cases Table (6).

Table (7) demonstrates the association of each of the victim's and assailants' characters and the type of sexual assault. There was a statistically significant association between gender of victim and the type of sexual assault $(\mathrm{p}<0.001)$. Sodomy was more frequent among males (91.2\%) while, rape, attempted rape, and mixed assault occurred only in females. In addition, sodomy was significantly more frequent (45.6\%) in younger age group of 3-7 years old while, rape, attempted rape, and mixed assault were significantly more reported in older age group more than 12 years old $(\mathrm{p}<0.001)$. Otherwise, there was no significant association between each of the victim's residence, mental state, whether died or not, the assailant's age, number, or relation to the victim and the type of sexual assault. 
Table (8) illustrates factors related to delayed disclosure of sexual assault by children. It was found that gender of victim was significantly related to delayed disclosure $(\mathrm{p}<0.001)$. Significantly higher percent of cases of delayed reporting were females (78.9\%) whereas; early reporting was significantly higher in males than females $(52.3 \%$ and $47.7 \%$ respectively). Besides, older ages 12-18 years old were more significantly related to delayed disclosure (73.3\%) while, the most frequent age group among early reported cases was 3-7 years old (40.0\%). Likewise, there was a statistically significant association between the assailant's age and the time of disclosure $(\mathrm{p}<0.020)$. In the majority (67.8\%) of cases of delayed disclosure, the assailant aged more than 18 years old. Regarding the association between the type of assault and the time of its reporting, it was found that anal sex (53.8\%) was significantly related to early reporting while, rape and attempted rape were significantly more frequent among cases with delayed disclosure $(40.0 \%$ and $30.0 \%$ respectively, $\mathrm{p}<0.001$ ).

Table (1): Chi-Square and Fisher's Exact tests for characters of victims of child sexual abuse in the studied years 2016-2018

\begin{tabular}{|c|c|c|c|c|c|c|c|c|c|c|}
\hline & \multicolumn{8}{|c|}{ Years } & \\
\hline & & \multicolumn{2}{|c|}{$\begin{array}{c}2016 \\
\mathrm{~N}=46 \\
(29.7 \%)\end{array}$} & \multicolumn{2}{|c|}{$\begin{array}{c}2017 \\
\mathrm{~N}=42 \\
(27.1 \%)\end{array}$} & \multicolumn{2}{|c|}{$\begin{array}{c}2018 \\
\mathrm{~N}=67 \\
(43.2 \%)\end{array}$} & \multicolumn{2}{|c|}{$\begin{array}{c}\text { Total } \\
\mathrm{N}=155 \\
(100 \%)\end{array}$} & \\
\hline & & $\mathrm{N}$ & $\%$ & $\mathrm{~N}$ & $\%$ & $\mathrm{~N}$ & $\%$ & $\mathrm{~N}$ & $\%$ & $P$ value \\
\hline \multirow[t]{2}{*}{ Gender } & Female & 36 & 78.3 & 25 & 59.5 & 41 & 61.2 & 102 & 65.8 & \multirow[t]{2}{*}{.103} \\
\hline & Male & 10 & 21.7 & 17 & 40.5 & 26 & 38.8 & 53 & 34.2 & \\
\hline \multirow{3}{*}{$\begin{array}{l}\text { Age groups } \\
\text { (years) }\end{array}$} & 3-7 & 12 & 26.1 & 12 & 28.6 & 20 & 29.9 & 44 & 28.4 & \multirow[t]{3}{*}{.603} \\
\hline & 8-12 & 6 & 13.0 & 4 & 9.5 & 13 & 19.4 & 23 & 14.8 & \\
\hline & $>12-18$ & 28 & 60.9 & 26 & 61.9 & 34 & 50.7 & 88 & 56.8 & \\
\hline \multirow[t]{2}{*}{ Residence } & Rural & 19 & 41.3 & 14 & 33.3 & 17 & 25.4 & 50 & 32.3 & \multirow[t]{2}{*}{.202} \\
\hline & Urban & 27 & 58.7 & 28 & 66.7 & 50 & 74.6 & 105 & 67.7 & \\
\hline \multirow[t]{2}{*}{ Victim } & Alive & 46 & 100.0 & 41 & 97.6 & 67 & 100.0 & 154 & 99.4 & \multirow[t]{2}{*}{.271} \\
\hline & Dead & 0 & 0.0 & 1 & 2.4 & 0 & 0.0 & 1 & 0.6 & \\
\hline \multirow{2}{*}{$\begin{array}{l}\text { Victim's } \\
\text { mental state }\end{array}$} & Normal & 46 & 100.0 & 42 & 100.0 & 66 & 98.5 & 154 & 99.4 & \multirow[t]{2}{*}{1.0} \\
\hline & Mongol & 0 & 0.0 & 0 & 0.0 & 1 & 1.5 & 1 & 0.6 & \\
\hline
\end{tabular}

$N$ : number $\quad P$ value $>0.05$ : non-significant

*significant at $P$ value $<0.05$

Table (2): Chi-Square and Fisher's Exact tests for distribution of the sexual assault types and delay time before disclosure according to the studied years 2016-2018

\begin{tabular}{|c|c|c|c|c|c|c|c|c|c|c|}
\hline & \multicolumn{8}{|c|}{ Years } & \\
\hline & & \multicolumn{2}{|c|}{$\begin{array}{c}2016 \\
\mathrm{~N}=46 \\
(29.7 \%)\end{array}$} & \multicolumn{2}{|c|}{$\begin{array}{c}2017 \\
\mathrm{~N}=42 \\
(27.1 \%)\end{array}$} & \multicolumn{2}{|c|}{$\begin{array}{c}2018 \\
\mathrm{~N}=67 \\
(43.2 \%) \\
\end{array}$} & \multicolumn{2}{|c|}{$\begin{array}{c}\text { Total } \\
\mathrm{N}=155 \\
(100 \%)\end{array}$} & \\
\hline & & $\mathrm{N}$ & $\%$ & $\mathrm{~N}$ & $\%$ & $\mathrm{~N}$ & $\%$ & $\mathrm{~N}$ & $\%$ & P value \\
\hline \multirow[t]{4}{*}{ Sexual assault type } & Anal sex & 10 & 21.7 & 18 & 42.9 & 29 & 43.3 & 57 & 36.8 & \multirow[t]{4}{*}{.070} \\
\hline & Attempted rape & 18 & 39.1 & 8 & 19.0 & 21 & 31.3 & 47 & 30.3 & \\
\hline & Rape & 17 & 37.0 & 13 & 31.0 & 14 & 20.9 & 44 & 28.4 & \\
\hline & Mixed & 1 & 2.2 & 3 & 7.1 & 3 & 4.5 & 7 & 4.5 & \\
\hline \multirow{2}{*}{$\begin{array}{l}\text { Delay time before } \\
\text { reporting (Disclosure) }\end{array}$} & $\leq 3$ days & 16 & 34.8 & 20 & 47.6 & 29 & 43.3 & 65 & 41.9 & \multirow[t]{2}{*}{.455} \\
\hline & $>3$ days & 30 & 65.2 & 22 & 52.4 & 38 & 56.7 & 90 & 58.1 & \\
\hline
\end{tabular}

$N$ : number $\quad P$ value $>0.05$ : non-significant

*significant at $P$ value $<0.05$

Table (3): Chi-Square and Fisher's Exact tests for the assailant's characters according to the studied years from 2016-2018

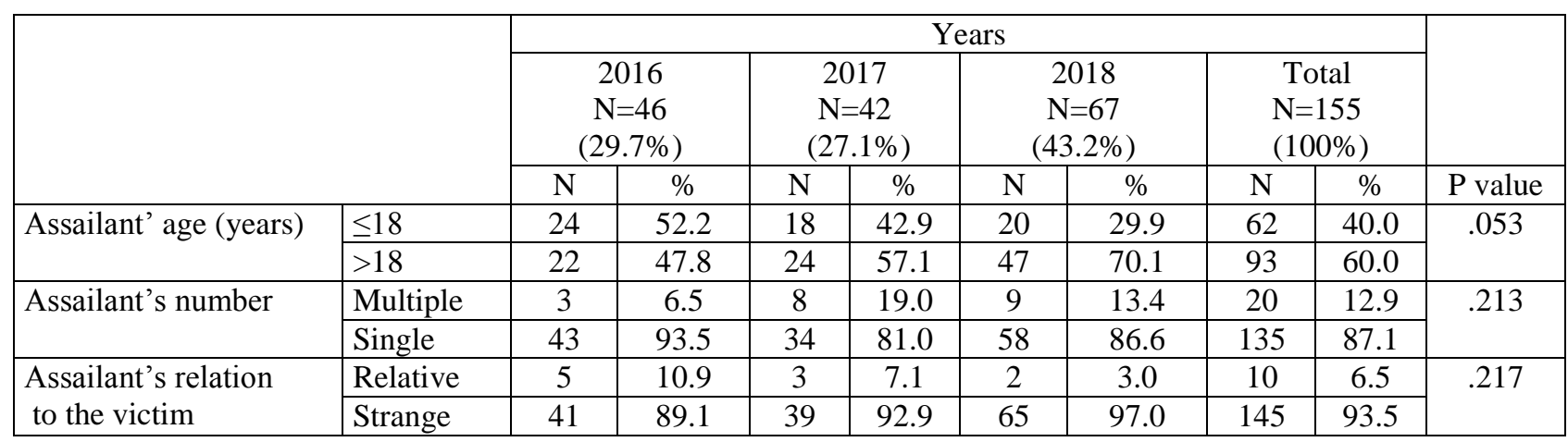

N: Number P value >0.05: non-significant

*significant at $P$ value $<0.05$ 
Table (4): Percentage of the sites and types of general injury of the studied victims of child sexual assault

\begin{tabular}{|l|l|c|c|}
\hline General violence & $\mathrm{N}=155$ & $\%$ \\
\hline \multirow{5}{*}{ Site of injury } & Limbs & 22 & 14.2 \\
\cline { 2 - 4 } & Face & 7 & 3.5 \\
\cline { 2 - 4 } & Face and limbs & 5 & 1.9 \\
\cline { 2 - 4 } & Back & 3 & 76.1 \\
\cline { 2 - 4 } & No & 118 & 12.9 \\
\hline \multirow{5}{*}{ Type of injury } & Abrasions & 20 & 7.1 \\
\cline { 2 - 4 } & Bruises & 11 & 3.2 \\
\cline { 2 - 4 } & Burn & 5 & 0.6 \\
\cline { 2 - 4 } & Bites & 118.1 \\
\cline { 2 - 4 } & No & & 76.9 \\
\hline
\end{tabular}

N: Number

Table (5): Percentage of findings of local examination of the studied victims (rape, attempted rape and mixed rape sodomy) of child sexual assault

\begin{tabular}{|c|c|c|c|}
\hline \multicolumn{2}{|c|}{ Local injuries in rape, attempted rape and mixed assault } & $\mathrm{N}=98$ & $\%$ \\
\hline \multirow[t]{2}{*}{ Labia majora } & No & 97 & 99.0 \\
\hline & yes & 1 & 1.0 \\
\hline Labia minora & No & 98 & 100.0 \\
\hline \multirow{2}{*}{$\begin{array}{l}\text { Posterior } \\
\text { fourchette }\end{array}$} & No & 96 & 98.0 \\
\hline & yes & 2 & 2.0 \\
\hline \multirow[t]{2}{*}{ Vaginal wall } & No & 96 & 98.0 \\
\hline & yes & 2 & 2.0 \\
\hline \multirow[t]{2}{*}{ perineum } & No & 97 & 99.0 \\
\hline & yes & 1 & 1.0 \\
\hline \multirow[t]{2}{*}{ Hymen injury } & No & 58 & 59.2 \\
\hline & yes & 40 & 40.8 \\
\hline \multirow[t]{3}{*}{ Vaginal swab } & No & 85 & 86.7 \\
\hline & positive & 8 & 8.2 \\
\hline & Negative & 5 & 5.1 \\
\hline
\end{tabular}

\section{N: Number}

Table (6): Percentage of findings of local examination of the studied victims (sodomy and mixed rape sodomy) of child sexual assault

\begin{tabular}{|c|c|c|c|}
\hline \multicolumn{2}{|c|}{ Local injuries sodomy and mixed assault } & $\mathrm{N}=64$ & $\%$ \\
\hline \multirow[t]{2}{*}{ Anal reflex } & Normal & 50 & 78.1 \\
\hline & weak & 14 & 21.9 \\
\hline \multirow[t]{2}{*}{ Sphincter tone } & Normal & 50 & 78.1 \\
\hline & Weak & 14 & 21.9 \\
\hline \multirow[t]{2}{*}{ Skin corrugation } & Normal & 50 & 78.1 \\
\hline & Flat & 14 & 21.9 \\
\hline \multirow[t]{2}{*}{ Anal opening } & Normal & 50 & 78.1 \\
\hline & Wide & 14 & 21.9 \\
\hline \multirow[t]{2}{*}{ Adjacent skin } & Normal & 53 & 82.8 \\
\hline & Bruises & 11 & 17.2 \\
\hline \multirow[t]{2}{*}{ Anal canal } & Normal & 50 & 78.1 \\
\hline & Flat & 14 & 21.9 \\
\hline \multirow[t]{3}{*}{ Tear of anal mucosa } & No & 42 & 65.6 \\
\hline & Old & 7 & 10.9 \\
\hline & Recent & 15 & 23.4 \\
\hline \multirow[t]{3}{*}{ Anal swab } & No & 56 & 87.5 \\
\hline & Positive & 5 & 7.8 \\
\hline & Negative & 3 & 4.7 \\
\hline
\end{tabular}

$N$ : Number 
Table (7): Chi-Square and Fisher's Exact tests for association of each of the victim's and assailants' characters in relation to the type of sexual assault

\begin{tabular}{|c|c|c|c|c|c|c|c|c|c|c|c|c|}
\hline & \multicolumn{10}{|c|}{ Sexual assault } & \multirow{3}{*}{$P$ value } \\
\hline & & \multicolumn{2}{|c|}{ Anal sex } & \multicolumn{2}{|c|}{$\begin{array}{l}\text { Attempted } \\
\text { rape }\end{array}$} & \multicolumn{2}{|c|}{ Rape } & \multicolumn{2}{|c|}{ Mixed } & \multicolumn{2}{|c|}{ Total } & \\
\hline & & $\mathrm{N}$ & $\%$ & $\mathrm{~N}$ & $\%$ & $\mathrm{~N}$ & $\%$ & $\mathrm{~N}$ & $\%$ & $\mathrm{~N}$ & $\%$ & \\
\hline \multirow[t]{2}{*}{ Gender } & Female & 5.0 & 8.8 & 47 & 100.0 & 44 & 100.0 & 7 & 100.0 & 102 & 65.8 & \multirow[t]{2}{*}{$<.001^{*}$} \\
\hline & Male & 52 & 91.2 & 0 & 0.0 & 0 & 0.0 & 0 & 0.0 & 53 & 34.2 & \\
\hline \multirow{3}{*}{$\begin{array}{l}\text { Victim's age } \\
\text { (years) }\end{array}$} & $>12-18$ & 10 & 17.5 & 29 & 61.7 & 43 & 97.7 & 6 & 85.7 & 88 & 56.8 & \multirow[t]{3}{*}{$<.001^{*}$} \\
\hline & $3-7$ & 26 & 45.6 & 17 & 36.2 & 1 & 2.3 & 0 & 0.0 & 44 & 28.4 & \\
\hline & 8-12 & 21 & 36.8 & 1 & 2.1 & 0 & 0.0 & 1 & 14.3 & 23 & 14.8 & \\
\hline \multirow[t]{2}{*}{ Residence } & Rural & 15 & 26.3 & 16 & 34.0 & 17 & 38.6 & 2 & 28.6 & 50 & 32.3 & \multirow[t]{2}{*}{.595} \\
\hline & Urban & 42 & 73.7 & 31 & 66.0 & 27 & 61.4 & 5 & 71.4 & 105 & 67.7 & \\
\hline \multirow[t]{2}{*}{ Victim } & Alive & 57 & 100.0 & 47 & 100.0 & 43 & 97.7 & 7 & 100.0 & 154 & 99.4 & \multirow[t]{2}{*}{.329} \\
\hline & Dead & 0 & 0.0 & 0 & 0.0 & 1 & 2.3 & 0 & 0.0 & 1 & 0.6 & \\
\hline \multirow{2}{*}{$\begin{array}{l}\text { Victim's } \\
\text { mental state }\end{array}$} & Normal & 57 & 100.0 & 46 & 97.9 & 44 & 100.0 & 7 & 100.0 & 154 & 99.4 & \multirow[t]{2}{*}{.632} \\
\hline & Mongol & 0 & 0.0 & 1 & 2.1 & 0 & 0.0 & 0 & 0.0 & 1 & 0.6 & \\
\hline \multirow{2}{*}{$\begin{array}{l}\text { Assailant's } \\
\text { number }\end{array}$} & Multiple & 5 & 8.8 & 6 & 12.8 & 8 & 18.2 & 1 & 14.3 & 20 & 12.9 & \multirow[t]{2}{*}{.579} \\
\hline & Single & 52 & 91.2 & 41 & 87.2 & 36 & 81.8 & 6 & 85.7 & 135 & 87.1 & \\
\hline \multirow{2}{*}{$\begin{array}{l}\text { Assailant's } \\
\text { relation }\end{array}$} & Relative & 1 & 1.8 & 6 & 12.8 & 3 & 6.8 & 0 & 0.0 & 10 & 6.5 & \multirow[t]{2}{*}{.148} \\
\hline & Strange & 56 & 98.2 & 41 & 87.2 & 41 & 93.2 & 7 & 100.0 & 145 & 93.5 & \\
\hline \multirow{2}{*}{$\begin{array}{l}\text { Assailant's } \\
\text { age (years) }\end{array}$} & $\leq 18$ & 25 & 43.9 & 20 & 42.6 & 14 & 31.8 & 3 & 42.9 & 62 & 40.0 & \multirow[t]{2}{*}{.621} \\
\hline & $>18$ & 32 & 56.1 & 27 & 57.4 & 30 & 68.2 & 4 & 57.1 & 93 & 60.0 & \\
\hline
\end{tabular}

Table (8): Chi-Square and Fisher's Exact tests for factors associated with delayed disclosure of child sexual assault

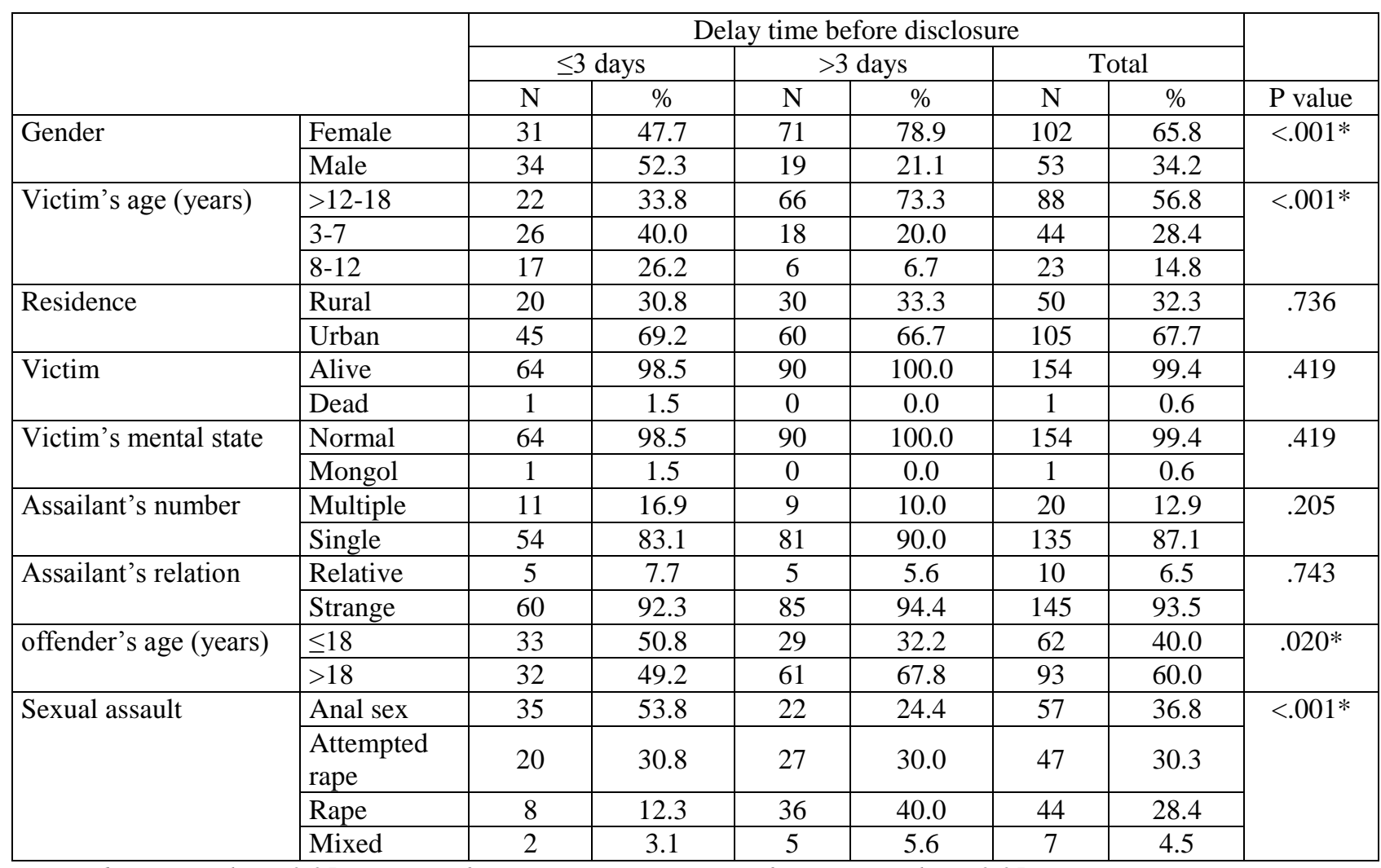

$N$ : Number $P$ value $>0.05$ : non-significant

\section{Discussion}

The present study demonstrated different medicolegal aspects of the problem of CSA in Benha region, Egypt. An important finding in this study was a significant association between female gender, older age groups, rape or attempted rape and delayed disclosure by the victims.

The current study revealed that the total number of reported cases of sexual assaults against children in Benha department, Egypt during the period 
of the study (2016 to 2018) was 155 cases. The highest percentage $(43.2 \%)$ of sexual assaults was encountered in 2018. Compared to this, an older study reported 321 cases of sexually abused boys during the period of 1986-1990 in the Medico-Legal department in Cairo, Egypt (Mohamed et al., 1995). Whereas, a prospective study evaluating sexual assault against children in Cairo governorate from 2012 to 2016 revealed much higher total number of 740(Abo-Seria et al., 2019). A Study in another Governorate in Egypt recorded 650 cases of sexual offenses in Dakahlia in the period from 1996 to 2000(Maklad et al., 2006). Lower frequencies (128 case) of CSA were reported to the medicolegal departments in Suez Canal area, from 2004 to 2009(Hagras et al., 2011). Much lower prevalence of 40 sexual assault cases was reported in Sohag Governorate from 2002 to 2003(Hilal et al., 2006). It seems that the prevalence of CSA is much higher in Cairo governorate which might be true figure related to the character of the area of the study or apparently due to more frequent reporting by the victims.

In the present study, the majority $(65.8 \%)$ of victims were females. This agrees with Hagras et al. (2011), Aboul-Hagag and Hamed (2012), Sohail et al. (2014) and Abo-Seria et al. (2019) who concluded that CSA is predominant in females than males. This might be attributed to the great attention and fear from parents and care givers paid to girls regarding sexual assault. This increases the rate of disclosure of sexual abuse. Alternatively, boys seem to resist disclosure of sexual abuse for the fear of punishment or humiliation (Maikovich-Fong \& Jaffee, 2010). Additionally, a Questioner based study which reported previous experiences of CSA among college students in Sohag University, Egypt explored a prevalence rate of $37.8 \%$ in females and $21.2 \%$ for males. This included screening questions about history of acts of non-contact, contact and/or intercourse CSA (Aboul-Hagag and Hamed, 2012). Internationally, 36\% of women in three central American countries reported that they experienced some type of sexual abuse in childhood (Speizer et al., 2008). In contrast, it has been reported that the number of male victims is greater during childhood (Magalhaes et al., 2009). Moreover, it has been stated that female victims predominate in older age groups while male ones are more encountered in younger age groups. They related this to the fact that Young males are often playing outdoors, not under the supervision of their families while, young females tend to stay close to their mothers (Thabet, 2008).

This study showed that more than half (56.8\%) of CSA victims were in the age group (12-18 years). This agrees with Arif et al. (2014) and Abo-Seria et al. (2019) who revealed that the child sexual assault was more predominant in the age group (11-18years). Though, CSA was more frequent among children of age group (6 - 12 years) than older children (11-18 years) as stated by Al-Mahroos and Al-Amer (2011) and AlMadani et al. (2012).

Regarding the residence of CSA victims, this study explored that more than two-thirds $(67.7 \%)$ of victims were from were urban cities while, $32.3 \%$ were from rural areas. This agrees with Hagras et al. (2011) who reported that all CSA victims in 2008 and 55.6\% of victims in 2004 were lived in urban areas in Suez Cana areas, Egypt.

In this study, only one child was died while the remaining 154 victims were alive. Regarding the Victim's mental state, only one victim in this study was mongoloid. Similarly, Elgendy and Hassan (2013) reported that only $1.9 \%$ of the victims had a mental disability.

The most frequently reported type of sexual abuse during the duration of this study was anal assault including anal sex only (36.8\%) and mixed analvaginal sex (4.5\%), followed by attempted rape (30.3\%), then 44 cases (28.4\%) were exposed to rape. Anal sex was more frequent among males (91.2\%) while, rape, attempted rape, and mixed assault occurred only in females. In addition, anal sex was significantly more frequent $(45.6 \%)$ in younger age group of 3-7 years old while, rape, attempted rape, and mixed assault were significantly more reported in older age group more than 12 years old. The pattern of CSA detected in this study is in agreement Elgendy and Hassan (2013) and Abo-Seria et al. (2019) who revealed higher frequency of anal sex in Cairo governorate (37.7\% and $55.0 \%$ respectively). Another study conducted by Metwaly et al. (2013) in Quena, Egypt reported similar result. In contrast another study reported that vaginal penetration was the most frequent (Maqsood et al., 2014).

The current study displayed that the nonrelative offenders (93.5\%) were more predominant than relative ones. This coincides Sharaf El-Din et al. (2015), Shetty et al. (2017), and Abo-Seria et al. (2019) who showed that perpetrators from outside the family were more predominant than from inside. However, Olsson et al. (2008) and Saint-Martin et al. (2014) reported that sexual abuse by intra-familial offenders were more common than that by extra-familial. An older study in Denmark highlighted that the reported relation of the perpetrator to the victim depends on the definition of CSA adopted by the researchers. When a broad definition including indecent exposure and intimate touching is applied, the offender was predominantly strange from the family. In contrast, when a narrow definition of sexual intercourse is used, the majority of cases took place in the child's family and in a nearby setting. So, consistent methods for defining and reporting cases of CSA are needed. There by treatment and preventive measure can be applied (Singh et al., 2014).

In the present study, majority of child sexual abuse cases were committed by one perpetrator (87\%) while $13 \%$ of cases were committed by more than one perpetrator. This agrees with Metwaly et al. (2013) who revealed that, most of child sexually abused cases were committed by one perpetrator. In contrast to the current results Arif et al. (2014) observed that, majority of child sexual abuse cases were committed by more than one perpetrator.

The majority (76.1\%) of child victims in this study showed no traumatic lesions in their body during 
general examination. Abrasions (12.9\%) were the most frequent wound in CSA cases, followed by bruises (7.1\%). Five cases (3.2\%) exposed to burn while only one case showed bites. Similarly, Abo-Seria et al. (2019) reported absence of signs general violence in the majority (87.7\%) of CSA victims, with bruises were the most frequent (6.1\%). Likewise, the medico-legal examination did not reveal any traumatic injuries in whole body in other studies Saint-Martin et al. (2014) and Waheb (2016). Alternatively, the series by White and McLean (2006) and Küçüker (2008) reported predominance of general violence with of traumatic injuries in the whole body of their victims

Medico-legal examination of vulvo-vaginal and perineal regions in the female victims exposed to rape, attempted rape and mixed vaginal-anal assault (98cases) revealed that both recent and old hymen tears were detected in $40.8 \%$ of cases. Vaginal swabs were taken from 13 cases, positive swabs for presence of semen were found in $8(8.2 \%)$ of the cases. The percentage of the detected hymen tears in this study is greater than that reported by Abo-Seria et al. (2019) in Cairo Governorate (28.8\%). Furthermore, Examination of anal region in cases of anal sex and in mixed rape and anal sex (64 cases) revealed signs of chronic habit of anal sex in 14 (21.9\%). This finding is much higher than that reported by Abo-Seria et al. (2019) in Cairo Governorate (3.6\%). This agrees with Al-Madani et al. (2012) and Elgendy and Hassan (2013) who found that most of child sexually abused cases showed intact hymen. Also, there is a similarity between these current results and a study conducted by EL-Sayed et al. (2017) who mentioned that anal injuries were evident in 15\%of child victims. This is in contrast with previous studies conducted by Pal et al. (2015) and Kaushik et al. (2016) who found that cases with old hymenal tear were more than those with intact hymen.

In ninety cases (58.1\%) of this study, the duration between the assault and reporting the incident was more than 3 days, with no significant differences between the three studied years. In accordance with this finding, Abo-Seria et al. (2019) reported that the majority of child abuse cases were examined after the sexual assault by more than one week $(40.4 \%)$ or after three days up to one week (25.5\%). In addition, Patra et al. (2015) reported that the majority of child cases were examined after the alleged assault by more than one week. In contrast, Sohail et al. (2014) and Ali et al. (2015) reported that greater frequency of reporting was within the first $72 \mathrm{hrs}$ of the alleged assault. Maqsood et al. (2014) assured that the time of reporting of CSA for medico-legal examination is very essential. This help documentation of injuries, collection of valid medical evidence.This work revealed significant association between female gender, older ages, rape and attempted rape and the frequency of delayed reporting. It's worth to mention that surveys reporting past history of sexual abuse among adults have recommended the role that peers play in the disclosure process. For maintenance of control over the disclosure process, the presence of opportunities to tell freely should be encouraged (McElvaney, 2015).

\section{Conclusion:}

Sexual child abuse is a problem in our society and presentation of cases was often delayed.

\section{Recommendations:}

There is a need for awareness programs to increase attention of the child, family and all society about how to respond to such situation. Female children should be encouraged by their families to report any attempt of sexual abuse early for proper documentation and protection of their rights. Furthermore, consistent objective methods for defining and reporting cases of CSA are required both in general hospitals and medicolegal institutions. There by proper preservation and collection of medical evidence could be achieved; to avoid the problem of lost data and the victim's rights.

\section{References}

Abo-seria M, Abdelrahman A, Mostafa $\mathrm{H}$ and Farag $\mathrm{H}$ (2019): Study of Child Sexually Abused Cases in Cairo Governorates in the Period from (2012) to (2016) \%J Ain Shams Journal of Forensic Medicine and Clinical Toxicology. 32, 31-39.

Aboul-Hagag k and Hamed A (2012): Prevalence and pattern of child sexual abuse reported by cross sectional study among the University students, Sohag University, Egypt. Egyptian Journal of Forensic Sciences, 2, 89-96.

Ali N, Akhter S, Nur Hossain N and Khan NT (2015): Rape in Rural Bangladesh. Delta Med Col J; 3(1); 31-35

Al-Madani O, Bamousa M, Alsaif D, Kharoshah MAA and Alsowayigh K (2012): Child physical and sexual abuse in Dammam, Saudi Arabia: A descriptive case-series analysis study. Egyptian Journal of Forensic Sciences, 33-37.

Al-Mahroos F and Al-Amer E, (2011): Reported child sexual abuse in Bahrain: 2000-2009. Annals of Saudi medicine, 16(8): 455-459.

Arif M, Ahmed M and Chaudhary KM, (2014): Medicolegal analysis of child and adolescent victims of sexual assault in Lahore- A Retrospective study. Professional Med J; 8(2):980-986.

Chen J., Cai Y., Cong E., Liu Y., Gao J., Li Y., Tao M., Zhang K. etal. (2014): Childhood sexual abuse and the development of recurrent major depression in Chinese women. PLoS One, 9, e87569.

Coburn P., Harvey M., Anderson S., Price H., Chong K. \& Connolly D. (2019): Boys Abused in a Community Setting: An Analysis of Gender, Relationship, and Delayed Prosecutions in Cases of Child Sexual Abuse. Journal of Child Sexual Abuse, 1-22.

El-Gendy IS and Hassan NA, (2013): Medico-legal study of child sexual abuse in greater Cairo, Egypt, during a 7-year period: 2005-2011. Am J Forensic Med Pathol, 34: 335-341

El-Sayed MR, Azab SM and El-Sayed A, (2017): Study of child abuse cases in Cairo and Giza governorates in the period from 2007 to 
2011.Forensic medicine, Ain Shams University, Thesis. Journal of child sexual abuse, 26(3):308-318.

Featherstone B., Morris K., Daniel B., Bywaters P., Brady G., Bunting l., Mason W., Mirza N. \& Review Y. (2017): Poverty, inequality, child abuse and neglect: Changing the conversation across the UK in child protection? Children and Youth Services Review, 97, 127-133.

Hagras A., Moustafa S., Barakat H. \& El-elemi A. (2011): Medico-Legal evaluation of child sexual abuse over a six-year period from 2004 to 2009 in the Suez Canal area, Egypt. Egyptian journal of forensic sciences, 1, 58-66.

Hilal M., Mohamed S. \& Aboul-hagag K. (2006): Sexual assaults in Sohag Governorate in two years (2002-2003). Sohag Med J, 10, 264-74.

Ingemann-hansen O. \& Charles A. (2013): Forensic medical examination of adolescent and adult victims of sexual violence. Best Pract Res Clin Obstet Gynaecol, 27, 91-102.

Kaushik N, Pal KS, Sharma A and Thakur CG (2016): A Retrospective Study of Sexual Assaults in Southern Range of Himachal Pradesh International Journal of Health Sciences and Research. Available at: www.ijhsr.org ISSN: 2249-957

Kim B, Park S and Park M (2017): The Relationship of Sexual Abuse with Self-Esteem, Depression, and Problematic Internet Use in Korean Adolescents. Psychiatry Investig, 14, 372-375.

Küçüker H (2008): Analysis of 268 child and adolescent victims of sexual assault and the legal outcome. Turkish Journal of Pediatric, 50: 313316.

Larsen KH and Larsen HB (2005): A critical review of available data on sexual abuse of children in Denmark. Child Abuse Negl,29:715-24.

Magalhaes T, Taveira F, Jardim P, Santos L, Matos E and Santos A (2009): Sexual abuse of children. A comparative study of intra and extra-familial cases. J Forensic Legal Med, 16(8): 455-459

Maikovich-Fong AK and Jaffee SR (2010): Sex differences in childhood sexual abuse characteristics and victim's emotional and behavioral problems: Findings from a national sample of youth. Child Abuse Negl, 34: 429437.

Maklad A., El-mehy I and El-shazly M (2006): A medico-legal study of sexual offences in Dakahlia Governorate. Zagazig J Forensic Med Toxicol, 4, 75-94.

Maqsood M, Arif M and Butt KM (2014): Incidence of Alleged Sexual Assault Cases in Lahore: It's Medico-legal and Social Aspects. Professional Med J, 8 (1):50-55.

McElvaney, R (2015): Disclosure of child sexual abuse: Delays, non-disclosure and partial disclosure. What the research tells us and implications for practice. Child Abuse Review, 24(3), 159-169.

Metwaly M, Ismail AM, Sherif MM, Mahmoud FS, Mohammed NI and Assasa FM (2013): Study about sexual offences in Quena governorates. J Forensic Res, 19, 2.

Mohamed F, El-din R \& El-zayat T (1995): Sexual abuse of boys in Cairo 1986-1990. MJFMCT, 3, 83-96.

Morris MC, Marco M, Maguire-Jack K, Kouros CD, Im W, White C, Bailey B, Rao U, Garber J (2019): County-level socioeconomic and crime risk factors for substantiated child abuse and neglect. Child Abuse Negl.90:127-138.

Mutavi T., Obondo A., Mathai M., Kokonya D. \& Dako-gyeke M (2018): Incidence of Selfesteem among Children Exposed to Sexual Abuse in Kenya. Global social welfare: research, policy \& practice, 5, 39-47.

Olsson A, Ellsberg E, Berglund S, Herrera A, Zlaya E , Pena R, et al. (2008): Sexual abuse during childhood and adolescence among Nicaraguan men and women: a population based anonymous survey. Child Abuse Negl, 24:1579-1589

Pal SK, Sharma A, Sehgal A and Rana A (2015): A study of sexual assault in northern range of Himachal Pradesh. Int J Med Toxicol Forensic Med; 5(2):64-72

Patra PA, Shaha KK, Rayamane PA and Mohanty S (2015): Victimology of alleged rape cases: A three -year institution based cross- sectional study Indian Journal of Forensic and Community Medicine, 2(4): 203-213.

Russell, DE H (1984): Sexual exploitation: Rape, child sexual abuse, and workplace harass-ment. Beverly Hills, CA: SAGE.

Saint-Martin P, Bouyssy M and O’Byrne P (2014): Analysis of 756 cases of sexual assault in Tours (France): medico-legal findings and judicial outcomes. J Gynecol Obstet Biol Reprod (Paris), 36(6): 588-94.[Article in French]

Sakelliadis E., Spiliopoulou C. \& Papadodima S (2009): Forensic investigation of child victim with sexual abuse. Indian Pediatr, 46, 144-51.

Sharaf El-Din AI, Elkholy MS, Eslam S and Farag HA (2015): Pattern of Female Sexual Assault in Qalyubia Governorate, Egypt, During the Period from 2009 to 2013: A Retrospective Study. The American Journal of Forensic Medicine and Pathology, 36 (4):276-284.

Shetty KC, Biradar G and Shetty P (2017): Sexual Assault in Ballari, Karnataka, India: A Four Year Retrospective Review. Arab Journal of Forensic Sciences \& Forensic Medicine, 7(2):35-40

Singh M., Parsekar S. \& Nair S (2014): An epidemiological overview of child sexual abuse. Journal of family medicine and primary care, 3, 430-435.

Sohail K, Parveen M, Nadeem S and Aslam M (2014): Female victims of sexualviolence; reported cases of in Faisalabad city in 2008. Professional Med, 17(4): 735-740. 
Speizer IS, Goodwin M, Whittle L, Clyde Maureen and Rogers J (2008): Dimensions of child sexual abuse before age 15 in three Central American countries: Honduras, El Salvador, and Guatemala.Child Abuse Negl;32:455-62.

Thabet HZ. (2008): Assessment of sexual assault cases in Assiut Governorate. Egypt J Forensic Sci Appl Toxicol;8(Suppl.):1.
Waheb MA (2016): Child Sexual Abuse in Fayoum Governorate, Egypt (2010-2014). J Forensic Res, 7: 332.

White C and McLean I (2006): Adolescent complainants of sexual assault; injury pattern in virgin and non- virgin groups. J Clin Forensic Med, 13(4): 172-180

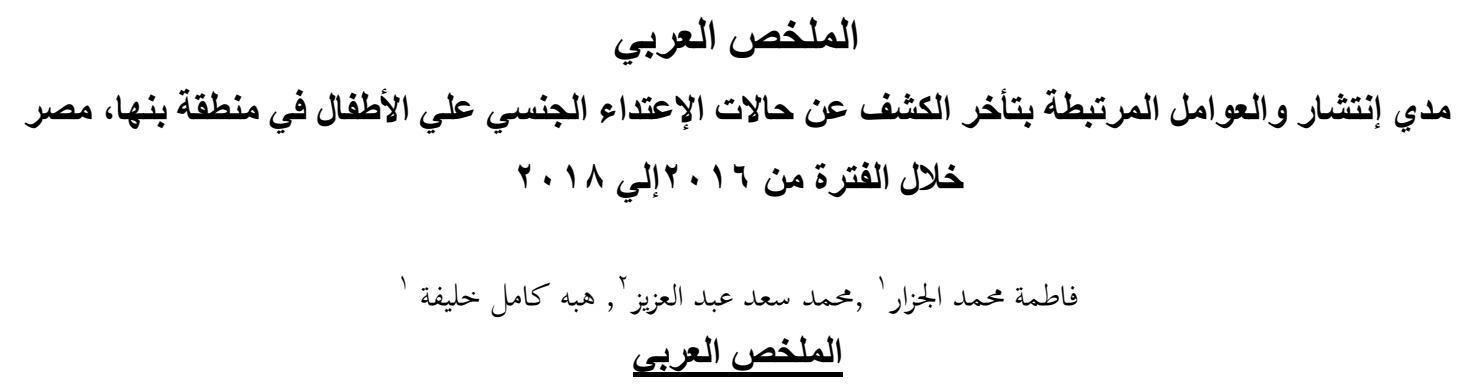

مقدمة: إن الاعتداء الجنسي علي الأطفال يعد إنتهاك خطير لحقوق الطفل، وهناك عواقب متنوعة تحدث لهؤلاء الأطفال سواء علي المدي القصير أو البعيد. كما يصعب تحديد معدلات الانتشار الفعلية للاعتداء الجنسي على الأطفال نتيجة عدم كشف الضحايا عنه. الهدف: تحدف هذه الدراسة إلى تقييم مدى إنتشار الاعتداء الجنسي على الأطفال وتحديد العوامل المرتبطة بتأخر الكشف عنه من قبل الضحايا.

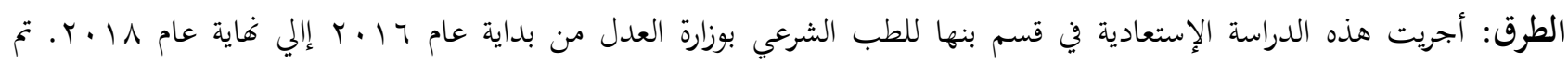
الحصول على التقرير الطبي الشرعي الخاص بالحالات من أجل الاطلاع علي البيانات الشخصية، وبيانات الاعتداء وبيانات الفحص العام والموضعي للضحية.

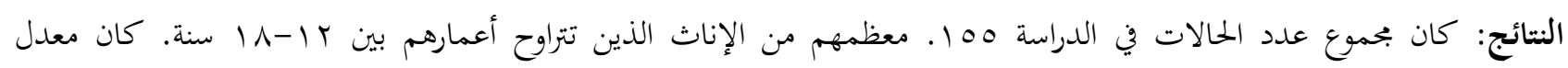
الإعتداء الجنسي الشرجي أكثر بين الذكور (ץ.|1.٪)، بينما كان حدوث الاغتصاب ومحاولة الاغتصاب والاعتداء الجنسي الشرجي

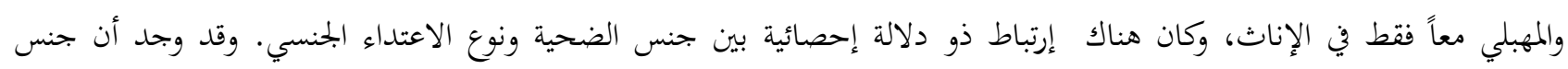
وعمرالضحية وكذلك عمر المعتدي مرتبط بدلالة إحصائية بتأخر الكشف عن الاعتداء الجنسي. الخلاصة: يشكل الاعتداء الجنسي على الأطفال مشكلة في بحتمعنا وغالبا ما تتأخر الضحايا في الكشف عنده التوصيات: ينبغي أن تشجع العائلات أطفالهم إلإناث بضرورة الابلاغ المبكر عن أي محاولة للإعتداء الجنسي في وقت مبكر للتوثيثق من أجل حماية حقوقهم، علاوة علي ذلك لابد من توافر طرق وقائمة فحص موحدة تخص حالات الاعتداء الجنسي على الأطفال في المستشفيات العامة ومصالح الطب الشرعي وذلك من أجل الحفاظ علي الأدلة وحقوق هؤلاء الضحايا. 